\title{
Effects of intensive scallop mariculture on macrobenthic assemblages in Sishili Bay, the northern Yellow Sea of China
}

\author{
Qingxi Han · Yueqi Wang • Yong Zhang • \\ John Keesing • Dongyan Liu
}

Received: 20 September 2012/Revised: 28 April 2013/Accepted: 2 June 2013

(C) Springer Science+Business Media Dordrecht 2013

\begin{abstract}
To elucidate the effects of scallop mariculture on the macrobenthic community in a moderate energy system, bimonthly samples from four transects along a distance gradient in Sishili Bay, the northern Yellow Sea of China, were investigated. Differences in macrobenthic community structure along the distance gradient were evaluated using univariate and multivariate analyses. The AZTI's Marine Biotic Index (AMBI) and multivariate-AMBI analyses indicated that the macrobenthic community suffered little disturbance from the scallop culture. Consistently, the
\end{abstract}

Handling editor: Stuart Jenkins

Q. Han · Y. Wang · Y. Zhang · D. Liu ( $₫)$

Key Laboratory of Coastal Zone Environmental Processes and Ecological Remediation, Yantai Institute of Coastal Zone Research (YIC), Chinese Academy of Sciences (CAS), 17 Chunhui Road, Yantai 264003, People's

Republic of China

e-mail: dyliu@yic.ac.cn

Q. Han · Y. Wang · Y. Zhang · D. Liu

Shandong Provincial Key Laboratory of Coastal Zone Environmental Processes, YICCAS, Yantai 264003, Shandong, People's Republic of China

Y. Wang

University of the Chinese Academy of Sciences, 100049 Beijing, People's Republic of China

J. Keesing

CSIRO Wealth from Oceans Flagship, Marine and

Atmospheric Research, Private Bag 5, Wembley,

WA 6913, Australia results of two-way analysis of similarities demonstrated that macrobenthic communities showed no difference along the distance gradient, but were significantly affected by the sampling months and transects. This conclusion was also confirmed by other univariate and multivariate analyses. The concentration of total organic carbon was $17.27 \pm 6.05 \mathrm{mg} \mathrm{g}^{-1}$, which is below the dangerous threshold of $35 \mathrm{mg} \mathrm{g}^{-1}$ toxic to benthic fauna. Combined results revealed that no detectable effects on the macrobenthic community were caused by intensive and long-term scallop culture in this moderate energy system. This is likely due to the influence of local hydrodynamics and it is recommended that intensive scallop farming be located in areas with strong tidal or current flows.

Keywords Macrobenthic community - Scallop mariculture $\cdot$ Environmental effect $\cdot$ Yellow Sea

\section{Introduction}

Mariculture of bivalves in suspended culture systems is attractive from economic and environmental standpoints, because good growth results can be achieved completely from naturally occurring organic food sources which can greatly reduce the culture cost and environmental pollution from the artificial food supplements (Yang \& Zhou, 1998; da Costa \& Nalesso, 2006; Gibbs, 2007; Fabi et al., 2009). Moreover, the benthos can also benefit from the suspended culture 
system. For example, the scallop cultivation structures can provide refuge for overfishing to endemic marine fishes and invertebrates in ways similar to artificial reefs, and may increase the productivity of some motile fishes and epifauna (Inglis \& Gust, 2003; Clynick et al., 2008; D'Amours et al., 2008; Han et al., 2011).

However, an intensive shellfish farming still can result in the accumulation of a large amount of organic matter on the seabed below the farm (Mirto et al., 2000; Grant et al., 2012) and a decrease of dissolved oxygen in seawaters (Kaiser, 2000). Consequently, some case studies have shown evidence of negative effects on benthic communities via the intense biodeposition of feces and pseudofeces (e.g., Gilbert et al., 1997; Smith \& Shackley, 2004; da Costa \& Nalesso, 2006; Dubois et al., 2007; Fabi et al., 2009). For example, a large quantity of organic biodeposition can dramatically decline the abundance of benthic fauna and species richness (Smith \& Shackley, 2004; da Costa \& Nalesso, 2006; Dubois et al., 2007). In the most serious cases, the opportunistic deposit-feeders will dominate in the benthic infauna (Smaal, 1991; Fabi et al., 2009) or even the seabed will be devoid of macrobenthic organisms (Grall \& Glémarec, 1997; Callier et al., 2008).

As the largest mariculture country around the world, China produced $62.3 \%$ of the global aquaculture production in quantity and $51.4 \%$ in value in 2008 , with an average annual growth rate of $10.4 \%$ over the period of 1970-2008 (FAO, 2010). Among all aquaculture taxa, the scallop culture occupied an area of $3,997 \mathrm{~km}^{2}$ (30.5\% of the total bivalve aquaculture area), with a production of 1.4 million tons $(12.7 \%$ of total bivalve production) in 2010. The growth rates of scallop cultivation area and production were 15.49 and $6.63 \%$ over the period of 2003-2010, and the production of the northern Yellow Sea contributed over $90 \%$ of total production in China (China Bureau of Fisheries, 2003-2011). In the future, the high demand for and high price of the scallop are expected to further accelerate the expansion of this kind of mariculture in current production areas.

With the rapid development of mariculture, more and more studies have focused on the ecological and environmental effects of intensive bivalve farming (Borja et al., 2009; Cranford et al., 2009; Fabi et al., 2009). The long-term sustainability of bivalve cultivation depends on the maintenance of the functional health of the natural ecosystem, and thus the evaluation of the effects of bivalve raft cultures on the underlying seabed environment is urgently recommended (Fabi et al., 2009). Macrobenthic communities have been used as bioindicators for monitoring coastal pollution and organic accumulation for a long time (Pearson \& Rosenberg, 1978; Shin et al., 2004; Gaudêncio \& Cabral, 2007) and have been proved to be a useful tool to monitor the sustainability of mariculture practices (da Costa \& Nalesso, 2006). However, previous studies have drawn distinctly different conclusions, and the impacts of shellfish culture were within the range from no or minimal negative effects to significantly positive and negative changes (Cranford et al., 2009). In China, despite the rapid growth of scallop cultivation, there are still few studies focusing on the changes of the macrobenthic community influenced by the intensive scallop raft farms. Sishili Bay, one of the earliest mariculture areas, established in the 1940s, is also one of the most intensively cultured areas in China and perhaps the world (Zhou et al., 2006). Suspended scallop aquaculture activity in Sishili Bay has been practiced for over three decades, with an estimated standing stock of 30,000 tons (Zhou et al., 2006). Thus Sishili Bay is a perfect area for the study of the long-term effects of intensive scallop mariculture activities. In the present study, bimonthly samples for 1 year were collected from four transects along a distance gradient in Sishili Bay, and univariate indices and multivariate analyses were applied to analyze the composition and structure of the macrobenthic community. Finally, the effects of intensive scallop mariculture on the macrobenthic community in Shishili Bay were evaluated with respect to the intensive and long-term bivalve cultivation in China.

\section{Methods}

Study area

This research was carried out bimonthly around Kongtong Island in Sishili Bay, a typical mariculture bay in the northern Yellow Sea, from January in 2011 to November in 2011. Sishili Bay, a $130 \mathrm{~km}^{2}$ semienclosed embayment, is located in the northeast of Shandong Province (the largest producer of cultured 
bivalves in China) on the Yellow Sea coast in northern China. The average water depth in Sishili Bay is 8-9 m (max. $20 \mathrm{~m})$, with a tidal range of $1.66 \mathrm{~m}$. Four small ephemeral rivers (Guangdang River, Majia River, Xin'an River, and Xiaoyuniao River) flow into the bay (Liu et al., 2012b); the longest one is the Xin'an River, with a length of $48.5 \mathrm{~km}$ and a maximum floodwater flux of $1,160 \mathrm{~m}^{3} \mathrm{~s}^{-1}$ (Zhou et al., 2006). The seawater temperature ranges from 23.3 to $27.4^{\circ} \mathrm{C}$ in summer (in June-August) to $-0.55^{\circ} \mathrm{C}$ in winter (in January 2011). The hydrodynamic processes in the bay are primarily controlled by the movement of tide and wind-induced currents. The tide currents primarily move back and forth in a northwest-southeast direction near Kongtong Island (Zhang \& Dong, 1990; Jia et al., 2007), with an average speed of $14.8 \mathrm{~cm} \mathrm{~s}^{-1}$ and a maximum current velocity of 28.5-30 $\mathrm{cm} \mathrm{s}^{-1}$ during ebb tides (Zhang \& Dong, 1990; this research). The sediments of the bay are very fine sand and coarse silt. The particle size of sediment in Sishili bay showed over 70\% similarity (Liu et al., 2012a).

Four transects of $500 \mathrm{~m}$ long [note: only 3 transects $(2,3,4)$ in January due to the bad weather] were positioned around the scallop farms and islands for macrobenthos sampling. For each transect, sediment samples were collected at four sites: under the culture ropes (farm site, named 01) and $40 \mathrm{~m}$ (named 02), $110 \mathrm{~m}$ (named 03) and $500 \mathrm{~m}$ (reference site, named 04) from the farm site along a linear gradient perpendicular to the farm boundary (Fig. 1). The sites were named according to the transect number and the distance number. In the sampling area, farming has been practiced near transects 2, 3, and 4 for over two decades at a depth of $9.5 \mathrm{~m}$, whereas farming has lasted near transect 1 for 5 years at depth of $18.5 \mathrm{~m}$.

The scallop cultivation structure is shown by diagrammatic drawings (Fig. 2). The floating rope is less than $150 \mathrm{~m}$, usually $80-130 \mathrm{~m}$. The lantern nets for cultivation are $0.5-1.0 \mathrm{~m}$ vertically apart from each other. One single lantern net is divided into 7-20 levels (20-25 cm high, usually 7-10 levels in the shallow water) by plastic disks of $30-60 \mathrm{~cm}$ in diameter. About 30-35 scallops about $2 \mathrm{~cm}$ large are settled in each level. The lantern nets are suspended at the depths of 1-6 m from the sea level and 4-6 m above the seabed. One lantern net with 10 levels can produce $20 \mathrm{~kg}$ scallop. The scallops principally
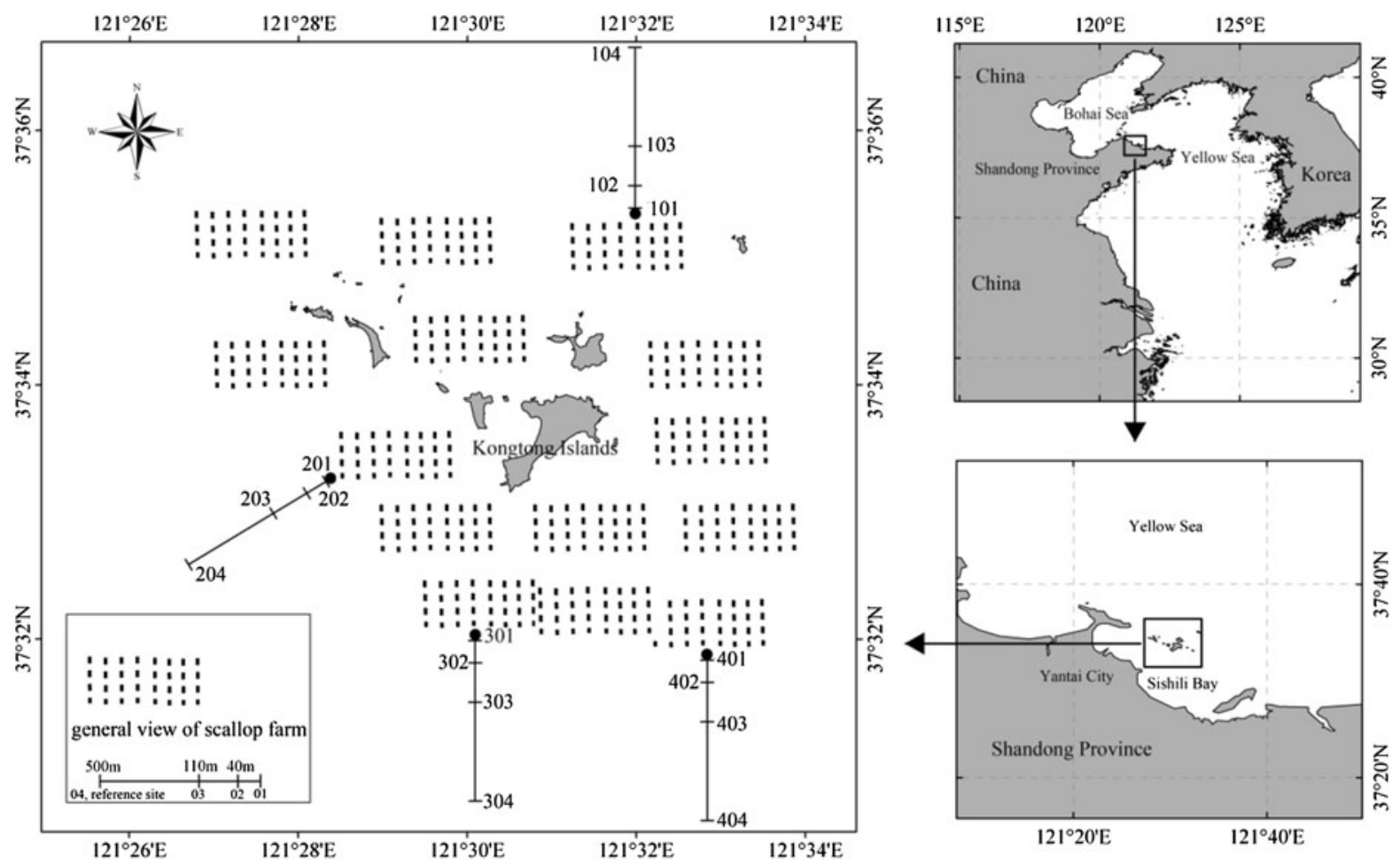

Fig. 1 Locations of the sampling transects and stations in Sishili Bay in 2011 
Fig. 2 a Picture of scallop farm taken in Sishili Bay; b Diagrammatic drawing for the scallop cultivation in Sishili Bay

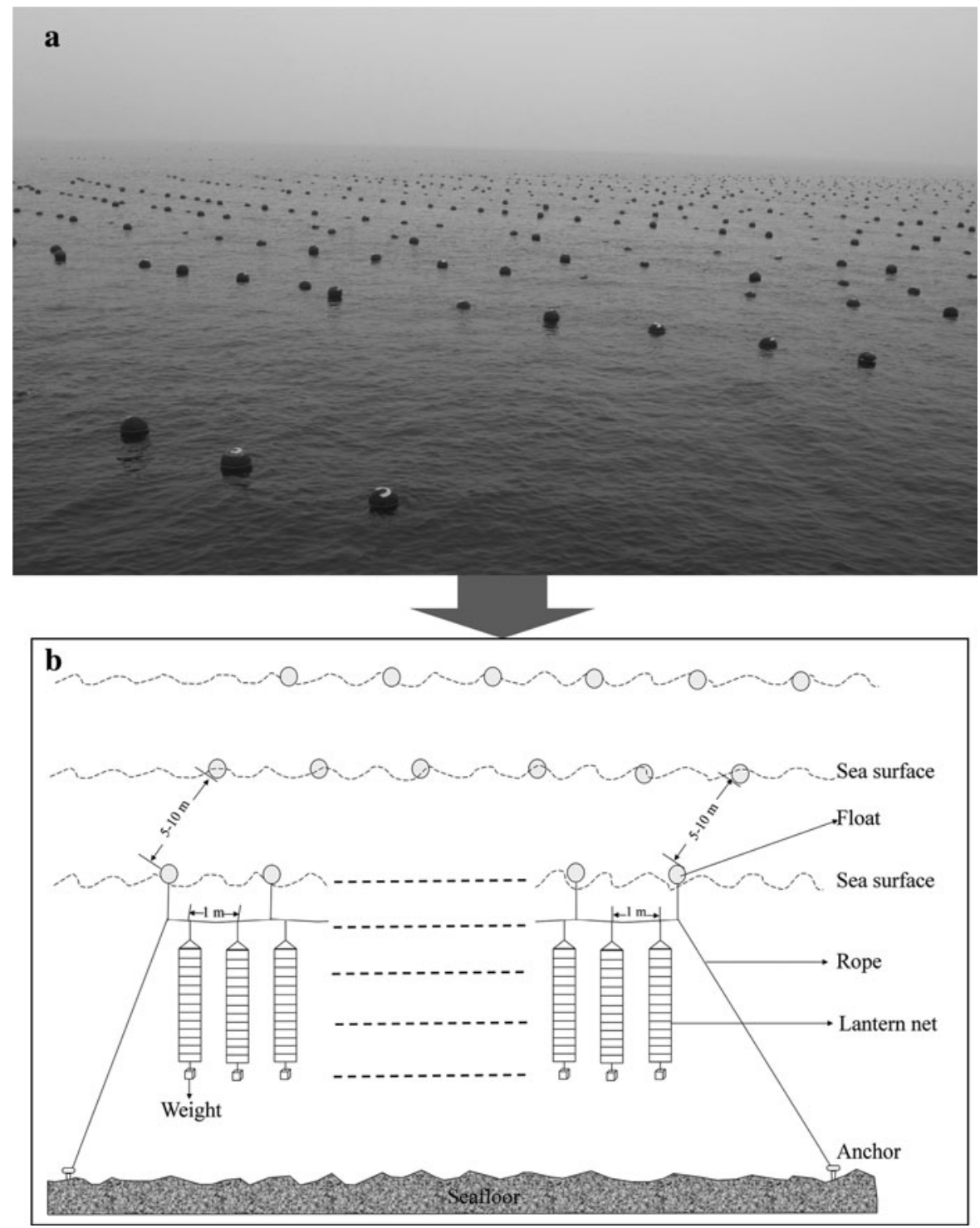

cultured around the Kongtong Islands are the endemic Chinese scallop Chlamys farreri (Jones et Preston, 1904) and the exotic bay scallop Argopecten irradians (Lamarck, 1819) (Liu, 2003; Zhou et al., 2006). The exotic bay scallop was introduced into China from USA in 1982 (Zhang et al., 1997), whereas the Chinese scallop naturally inhabits the cold temperate hardsubstrate coasts of northern China, Korea, Japan, and eastern Russia in areas with unblocked water flow, clean water, and high salinity. Scallop cultured has shifted from $C$. farreri to the bay scallop A. irradians, primarily due to the high summer mortality rate of the former species. Growout of the bay scallop is achieved in 1 year, and that of the Chinese scallop is achieved in 1.5-2 years.

\section{Data collection}

Sampling was conducted bimonthly from January to November in 2011. At each site, four samples were collected using a $0.05 \mathrm{~m}^{2}$ Van Veen grab. Three of these samples were washed in situ through a $0.5 \mathrm{~mm}$ mesh screen, and the filtered macrobenthos were preserved in $95 \%$ ethyl alcohol to be analyzed in the laboratory. The $4^{\text {th }}$ sample was used to analyze the characteristics of sediment. The macrofauna was sorted 
through a stereo- and binocular microscope after staining with Rose Bengal, identified to the lowest possible taxonomic level, quantified and weighed.

Environmental parameters, including temperature, depth, salinity, dissolved oxygen (DO), and $\mathrm{pH}$, were examined by Yellow Spring Instruments (YSI, Ohio, USA). The mean grain size $[d(0.5)]$ was measured using a Mastersizer 2000 Laser Particle Sizer (Malvern Instruments Limited, UK), which is capable of measuring grain sizes from 0.02 to $2,000 \mu \mathrm{m}$ with a relative error of less than $1 \%$. Total organic carbon (TOC), Total Nitrogen (TN), and Sulfur were examined using a vario MICRO CUBE (Elementar, Germany).

\section{Data analyses}

Benthic community data were standardized (ind. $\mathrm{m}^{-2}$ ) and then processed using both univariate and multivariate statistical analyses. Biological properties, including abundance $(N)$, the number of species $(S)$, the Shannon-Wiener diversity index $\left(H^{\prime}\right.$, calculated using base-10 logarithms), the Margalef richness index $(d)$, and Pielou's evenness index $\left(J^{\prime}\right)$, were calculated at each sampling site and sampling month.

To evaluate spatial and temporal changes in species abundance, a multivariate technique was applied using the PRIMER 6.0 ecological software package developed by the Plymouth Marine Laboratory. Macrobenthic abundance data were square root transformed to reduce the contribution of prevalent taxa and, therefore, increase the importance of less abundant species before all subsequent analyses. A similarity matrix was constructed using the Bray-Curtis similarity index after calculating the relative contributions of each species to the average similarities of these groupings. Ordination was computed via hierarchical cluster analysis (CLUSTER) using group-average sorting and non-metric multidimensional scaling (MDS). Seriation test and SIMPER (Similarity percentages) analysis were also performed to analyze the community structure. Pearson's correlations between macrobenthic indices $\left(S, N, H^{\prime}, d\right.$ and $\left.J^{\prime}\right)$ and sediment parameters $[d(0.5)$, TOC, TN and Sulfur $]$ were calculated using the SPSS 18.0 package.

AZTI's Marine Biotic Index (AMBI) and multivariate-AMBI (m-AMBI) were used to analyze benthic ecological status using AMBI software (version 5.0, downloaded from www.azti.es) on the basis of the
AMBI guidelines (Borja \& Muxika, 2005). The threshold values for the AMBI (Pinto et al., 2009) are as follows: "normal," $0.0-1.2$; "slightly polluted," 1.2-3.3; "disturbed," 3.3-5.0; "heavily disturbed," 5.0-6.0; and "extremely disturbed," Azoic. The quality threshold values for the m-AMBI (Borja \& Tunberg, 2011) are as follows: "high," >0.77; "good," 0.53-0.77; "moderate," 0.38-0.53; "poor," $0.20-0.38$; and "bad," $<0.20$.

\section{Results}

Community composition

Altogether 20,880 specimens were collected in the entire sampling period, comprising 209 species, 165 genera, 108 families, and 13 phyla. Polychaeta was the most speciose group with 80 taxa (38.28\%), followed by Mollusca with 53 taxa (25.35\%), Crustacea with 52 taxa $(24.88 \%)$, Echinodermata with 13 taxa (6.22\%), and 11 taxa $(5.26 \%)$ from other phyla including Urochordata, Nemertea, Coelenterata, Hemichordata, Platyhelminthes, Porifera, Sipuncula, Branchiopda, and Arthropoda. The total species abundance showed that the macrobenthic community was constituted by Polychaeta (62.76\%), Crustacea (25.04\%), Mollusca $(7.78 \%)$, Echinodermata $(3.75 \%)$, and other groups $(0.67 \%)$. The 20 most abundant species comprised $77.36 \%$ of the total abundance when pooling all sampling periods (Table 1). Among all the sampling periods, Lumbrineris latreilli Audouin et Edwards, 1834 and Paranthura japonica Richardson, 1909 were the most abundant and prevalent species. The polychaete $L$. latreilli and the crustacean $P$. japonica comprised 19.9-31.0 and $6.9-16.9 \%$ of the total abundance, respectively (Fig. 3).

\section{Comparison of univariate indices}

The univariate indices including $S, N, d, J^{\prime}$, and $H^{\prime}$ were calculated using Primer 6.0. The differences of these indices among sampling month, transect, and distance gradient were assessed using three-way ANOVA (analysis of variance) by SPSS 18.0. Transect was introduced as a random factor, and both distance and sampling season were introduced as fixed factors. $S$ and $d$ were significantly different from each other among the sampling months, whereas $N$ and $H^{\prime}$ 
Table 1 The abundance (ind. $\mathrm{m}^{-2}$ ) of the 20 most abundant macrobenthic species sampled in Sishili Bay in 2011

\begin{tabular}{|c|c|c|c|c|c|}
\hline Species & Farm & $40 \mathrm{~m}$ & $110 \mathrm{~m}$ & Reference & Total \\
\hline Lumbrineris latreilli Audouin et Edwards, 1834 & 432.5 & 437.2 & 393.9 & 381.5 & $1,645.1$ \\
\hline Paranthura japonica Richardson, 1909 & 181.5 & 183.5 & 191.4 & 128.0 & 684.4 \\
\hline Heteromastus filiformis (Claparede, 1864) & 150.8 & 115.3 & 97.1 & 73.5 & 436.7 \\
\hline Pista cristata (Müller, 1776) & 83.7 & 79.3 & 70.5 & 64.1 & 297.6 \\
\hline Eriopisella sechellensis (Chevreux, 1901) & 94.2 & 66.0 & 65.4 & 60.0 & 285.6 \\
\hline Amphioplus japonicus (Matsumoto, 1915) & 81.8 & 87.4 & 54.9 & 11.8 & 235.9 \\
\hline Nephtys polybranchia Southem, 1921 & 52.8 & 51.6 & 47.3 & 53.1 & 204.8 \\
\hline Amaeana occidentalis (Hartman, 1944) & 36.0 & 42.3 & 35.4 & 29.0 & 142.7 \\
\hline Notomastus latericeus Sars, 1857 & 34.5 & 34.5 & 33.8 & 38.0 & 140.8 \\
\hline Apseudes sp. & 29.3 & 42.5 & 29.0 & 29.0 & 129.8 \\
\hline Moerella iridescens (Benson, 1842) & 22.2 & 22.2 & 24.4 & 28.9 & 97.6 \\
\hline Sigambra bassi (Hartman, 1974) & 20.6 & 20.0 & 24.7 & 25.2 & 90.5 \\
\hline Poecilochaetus serpens Allen, 1904 & 20.2 & 28.1 & 19.4 & 19.4 & 87.1 \\
\hline Leptomya minuta Habe, 1960 & 27.8 & 13.6 & 15.4 & 22.0 & 78.8 \\
\hline Aricidea fragilis Webster, 1879 & 14.6 & 18.9 & 21.0 & 21.7 & 76.2 \\
\hline Paralacydonia paradoxa Fauvel, 1913 & 23.3 & 18.3 & 16.5 & 16.1 & 74.2 \\
\hline Endopleura lubrica (Gould, 1861) & 20.0 & 12.2 & 21.8 & 19.1 & 73.1 \\
\hline Magelona cincta Ehlers, 1908 & 13.2 & 16.7 & 18.6 & 23.9 & 72.4 \\
\hline
\end{tabular}

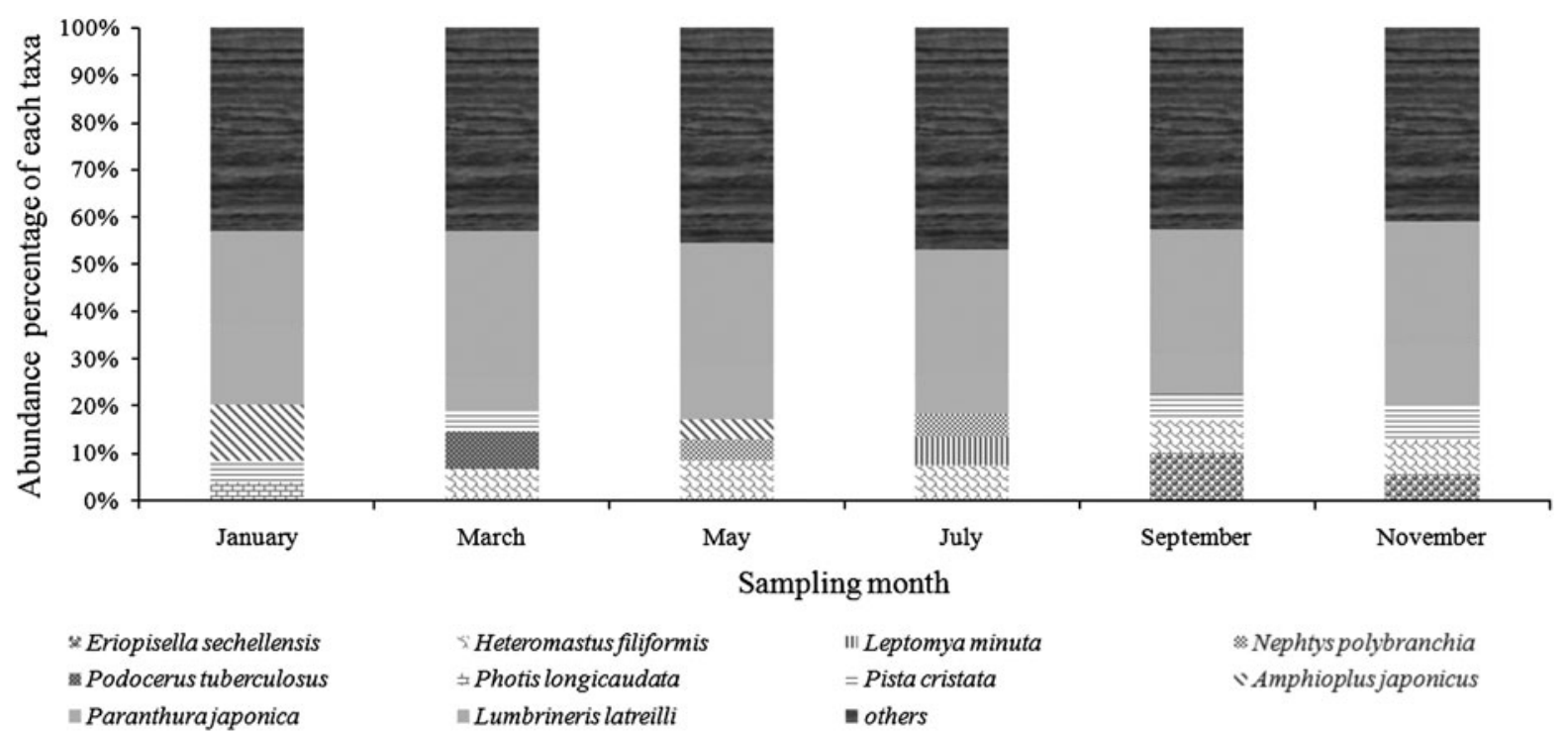

Fig. 3 Proportions of the five most abundant species compared to total abundance in the six sampling months

were different from each other among transects while $J^{\prime}$ was significantly different, and no indices differed along the distance gradient. $S$ varied significantly between different sampling months $(F=8.04$, $P<0.01)$. Total abundance $(N)$ differed among transects $(F=4.42, P<0.05)$. The $d$ index showed significant differences among months $(F=6.40$, $P<0.01)$. The $J^{\prime}$ only differed among transects $(F=6.41, P<0.01)$. The $H^{\prime}$ differed among transects $(F=4.79, P<0.05)$. None of these indices 
differed along the gradient, so the macrobenthic community showed no significant change along the distance gradient away from the scallop farm.

Spearman rank correlation was performed to analyze the relationships between the macrobenthic community structure and the environmental parameters including depth, TN\%, TOC\%, Sulfur\%, and mean grain size $[d(0.5)]$. The results indicated that Sulfur\% was the only factor significantly correlated with macrobenthic community structure $(0.01<P<0.05)$. The community structure appeared to show no relevance to other environmental factors, including TN $(R=0.009$, $P>0.05)$, TOC $(R=0.036, P>0.05)$, and mean grain size $(R=0.041, P>0.05)$ (Table 2$)$.

\section{Comparison of community structure}

The results of two-way analysis of similarities (ANOSIM) and pairwise test indicated highly significant spatial $(R=0.774, P<0.01)$ and temporal differences $(R=0.605, P<0.01)$. Meanwhile, macrobenthic communities showed no differences along the distance gradient (Global $R=-0.166, P>0.05$ ). Taking the low similarity of the four transects into account, one-way ANOSIM was also performed to test the difference along the distance gradient within each transect. The results of the pairwise test showed that the only significant difference was present between sites 201 (farm site of transect 2) and 204 (reference site of transect 2) $(R=0.257, P<0.01)$ : the farm site had more individuals than the reference site. With the subsequent SIMPER analysis, the average dissimilarity of 201 and 204 was $55.00 \%$, and the primary contributors were Amphioplus japonicus (4.11\% contribution) and $P$. japonica $(4.11 \%$ contribution) (Table 3).

The MDS ordination with the abundance of individuals showed that the sampling sites appeared to cluster into five groups at a $40 \%$ similarity level, and the ANOSIM analysis confirmed this result $(R=0.852$, $P<0.01)$. January was significantly different from the other sampling months. However, this result should be excluded because of its high 2D stress value (stress value $=0.21>0.20$, values of stress in the range of $0.2-0.3$ should be treated with a great deal of skepticism and certainly discarded) (Clarke \& Gorley, 2001). The MDS and CLUSTER analyses revealed obvious monthly trends in the macrobenthic community overall. For further analysis, MDS and CLUSTER analyses were performed on the macrobenthic abundance data for every sampling month. These analyses showed significant differences between transect groups. Transects 3 and 4 were separated from each other at a relatively high similarity level of approximately $60 \%$ (except for $40 \%$ in January). However, it seemed that the macrobenthic community was not different along the distance gradient (Figs. 4 and 5). A Seriation test was also performed for each transect and sampling month (Table 4). There was no discernible biotic pattern along the distance gradient from the scallop farm for each transect. The Index of Multivariate Seriation (IMS) varied from -0.37 to 0.93 , and the

Table 2 Correlation matrix with $P$ values between biological indices and environmental variables

\begin{tabular}{|c|c|c|c|c|c|c|c|c|c|}
\hline & $S$ & $N$ & $d$ & $J^{\prime}$ & $H^{\prime}\left(\log _{10}\right)$ & ТOC\% & $\mathrm{S} \%$ & $\mathrm{~N} \%$ & $d(0.5)$ \\
\hline$N$ & $0.000 * *$ & & & & & & & & \\
\hline d & $\mathbf{0 . 0 0 0} * *$ & 0.032* & & & & & & & \\
\hline$J^{\prime}$ & 0.300 & $0.000 * *$ & $0.042 *$ & & & & & & \\
\hline$H^{\prime}$ & $0.002 * *$ & $0.000 * *$ & $0.000 * *$ & $0.000 * *$ & & & & & \\
\hline ТOC\% & 0.925 & 0.582 & 0.812 & 0.365 & 0.543 & & & & \\
\hline Sulfur & 0.405 & $0.027 *$ & 0.629 & 0.096 & 0.300 & $0.000 * *$ & & & \\
\hline $\mathrm{TN} \%$ & 0.827 & 0.554 & 0.470 & 0.816 & 0.981 & $0.000 * *$ & $0.000 * *$ & & \\
\hline$d(0.5)$ & 0.867 & 0.899 & 0.920 & 0.949 & 0.916 & $0.000 * *$ & $0.000 * *$ & 0.775 & \\
\hline Depth & 0.536 & 0.290 & 0.233 & 0.459 & 0.320 & 0.997 & 0.342 & 0.235 & 0.279 \\
\hline
\end{tabular}


Table 3 Two-way crossed ANOSIM between month-transect and month-distance (left); one-way ANOSIM pairwise test between different transects (right) using PRIMER 6.0

\begin{tabular}{|c|c|c|c|c|c|}
\hline & $R$ statistic & $\begin{array}{l}\text { Significance } \\
\text { level }(\%)\end{array}$ & & $R$ statistic & $\begin{array}{l}\text { Significance } \\
\text { level }(\%)\end{array}$ \\
\hline Month & Global $R: 0.605$ & $0.1 * *$ & Transect 1 & Global $R:-0.116$ & 99.2 \\
\hline Jan-Mar & 0.767 & $0.1 * *$ & Farm-40 m & -0.1 & 91.3 \\
\hline Jan-May & 0.83 & $0.1 * *$ & Farm-110 m & -0.144 & 96.8 \\
\hline Jan-Jul & 0.865 & $0.1 * *$ & Farm-reference & -0.04 & 65.1 \\
\hline Jan-Sep & 0.882 & $0.1 * *$ & $40 \mathrm{~m}-110 \mathrm{~m}$ & -0.2 & 100 \\
\hline Jan-Nov & 0.844 & $0.1 * *$ & $40 \mathrm{~m}$-reference & -0.104 & 73.8 \\
\hline Mar-May & 0.589 & $0.1 * *$ & $110 \mathrm{~m}$-reference & -0.188 & 99.2 \\
\hline Mar-Jul & 0.857 & $0.1 * *$ & Transect 2 & Global $R:-0.014$ & 54.8 \\
\hline Mar-Sep & 0.688 & $0.1 * *$ & Farm-40 m & -0.15 & 95.7 \\
\hline Mar-Nov & 0.682 & $0.1 * *$ & Farm-110 m & -0.124 & 90 \\
\hline May-Jul & 0.471 & $0.1 * *$ & Farm-reference & 0.257 & $0.4 * *$ \\
\hline May-Sep & 0.667 & $0.1 * *$ & $40-110 \mathrm{~m}$ & -0.163 & 95.5 \\
\hline May-Nov & 0.596 & $0.1 * *$ & $40 \mathrm{~m}$-reference & 0.139 & 7.1 \\
\hline Jul-Sep & 0.831 & $0.1 * *$ & $110 \mathrm{~m}$-reference & -0.019 & 54.1 \\
\hline Jul-Nov & 0.849 & $0.1 * *$ & Transect 3 & Global $R:-0.055$ & 90 \\
\hline Sep-Nov & 0.26 & $0.5^{* *}$ & Farm-40 m & -0.12 & 96.3 \\
\hline Transect & Global $R: 0.774$ & $0.1 * *$ & Farm-110 m & -0.159 & 98.9 \\
\hline $1-2$ & 0.802 & $0.1 * *$ & Farm-reference & 0.039 & 26.2 \\
\hline $1-3$ & 0.863 & $0.1 * *$ & $40 \mathrm{~m}-110 \mathrm{~m}$ & -0.109 & 92.4 \\
\hline $1-4$ & 0.94 & $0.1 * *$ & $40 \mathrm{~m}$-reference & 0.031 & 32.5 \\
\hline $2-3$ & 0.776 & $0.1 * *$ & $110 \mathrm{~m}$-reference & -0.035 & 66.7 \\
\hline $2-4$ & 0.766 & $0.1 * *$ & Transect 4 & Global $R:-0.06$ & 85.2 \\
\hline $3-4$ & 0.795 & $0.1 * *$ & Farm-40 m & -0.1 & 87.2 \\
\hline Distance & Global $R:-0.166$ & 100 & Farm-110 m & -0.013 & 47.4 \\
\hline Farm-40 m & -0.194 & 99.2 & Farm-reference & -0.028 & 60.4 \\
\hline Farm-110 m & -0.154 & 98.4 & $40 \mathrm{~m}-110 \mathrm{~m}$ & -0.054 & 67.1 \\
\hline Farm-reference & -0.097 & 92.1 & $40 \mathrm{~m}$-reference & -0.059 & 72.7 \\
\hline $40 \mathrm{~m}-110 \mathrm{~m}$ & -0.228 & 99.9 & $110 \mathrm{~m}$-reference & -0.15 & 93.9 \\
\hline $40 \mathrm{~m}$-reference & -0.15 & 98.9 & & & \\
\hline 110 m-reference & -0.181 & 98.3 & & & \\
\hline
\end{tabular}

relationship between community structure and distance gradient was very non-monotonic $(P>0.05)$. The major dissimilarity in the pairwise comparison among all sampling months agreed well with the results of the MDS and CLUSTER analyses.

\section{AMBI and m-AMBI indices}

According to the AMBI results, only site 404 in November was heavily disturbed (AMBI value: 6.77), and 10 sites were "normal," with values from 0.85 to 1.16, whereas the other 81 sites were "slightly polluted," with values from 1.22 to 2.88 . We compared the AMBI values between different distances, transects, and sampling months using multi-variable ANOVA. The outputs of the multi-variable ANOVA showed that AMBI was not influenced by transect $(F=0.648 ; P>0.05)$, distance $(F=0.606 ; P>$ $0.05)$, or sampling month $(F=1.210 ; P>0.05)$. According to the m-AMBI output, only 2 sites (site 101 in May, m-AMBI value $=0.50$; site 404 in November, $\mathrm{m}$-AMBI value $=0.51$ ) had a "moderate" ecological status (ES), whereas 23 sites had a "good" ES, and the other sites had a "high" ES. We compared 

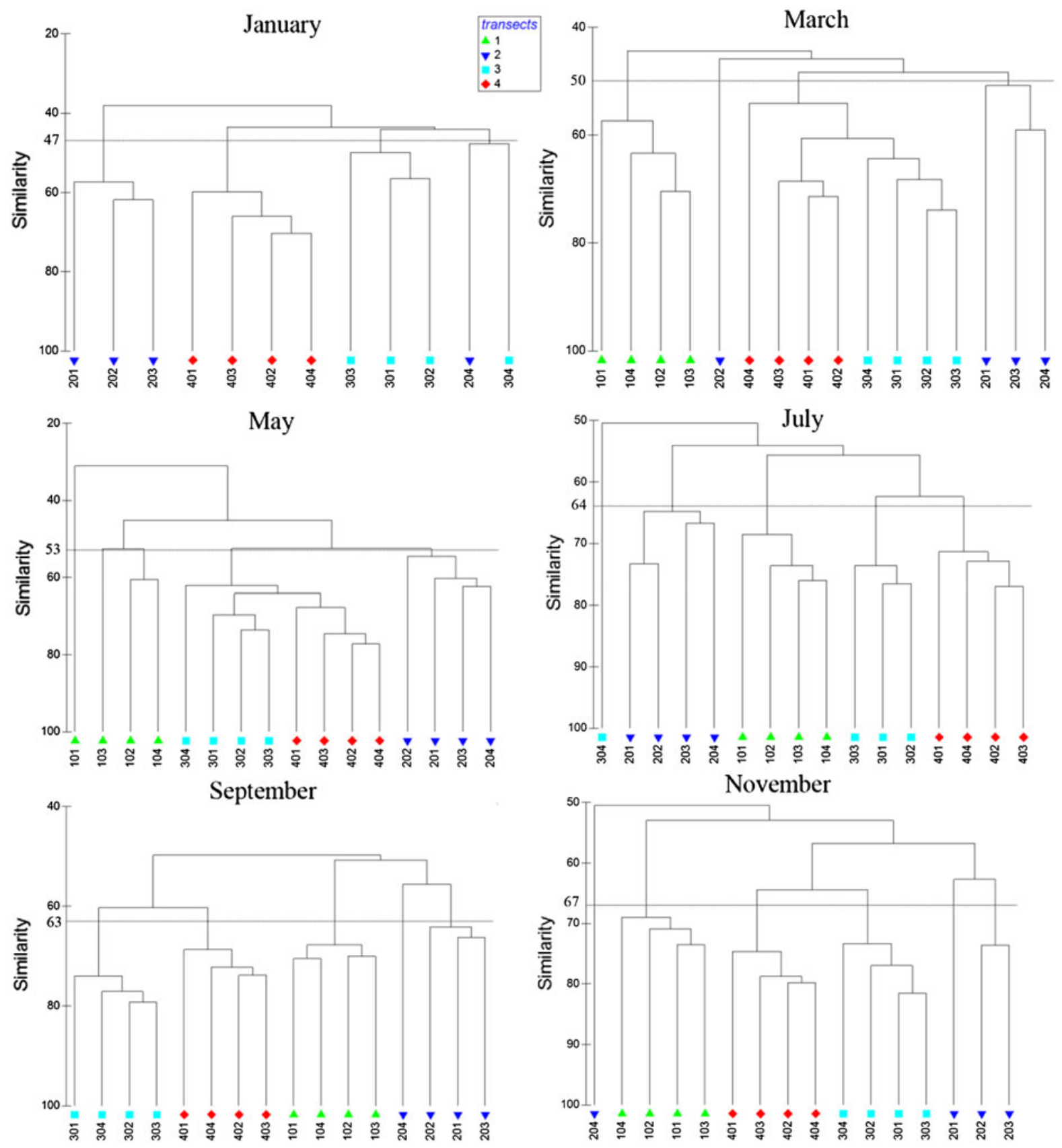

Fig. 4 Dendrogram of hierarchical clustering using group-average linking in each sampling month

the m-AMBI values between different distances, transects, and sampling months using multi-variable ANOVA. The outputs of the ANOVA showed that m-AMBI only significantly varied between different months $(F=5.302 ; P<0.01)$. The m-AMBI value was not different between transects
(ANOVA, m-AMBI, $F=2.442, P>0.05$ ) or distances (m-AMBI, $F=0.178, P>0.05$ ). Both the AMBI and $\mathrm{m}$-AMBI values showed that the macrobenthic communities of site 101 in May and site 404 in November were subjected to the strongest disturbances. 

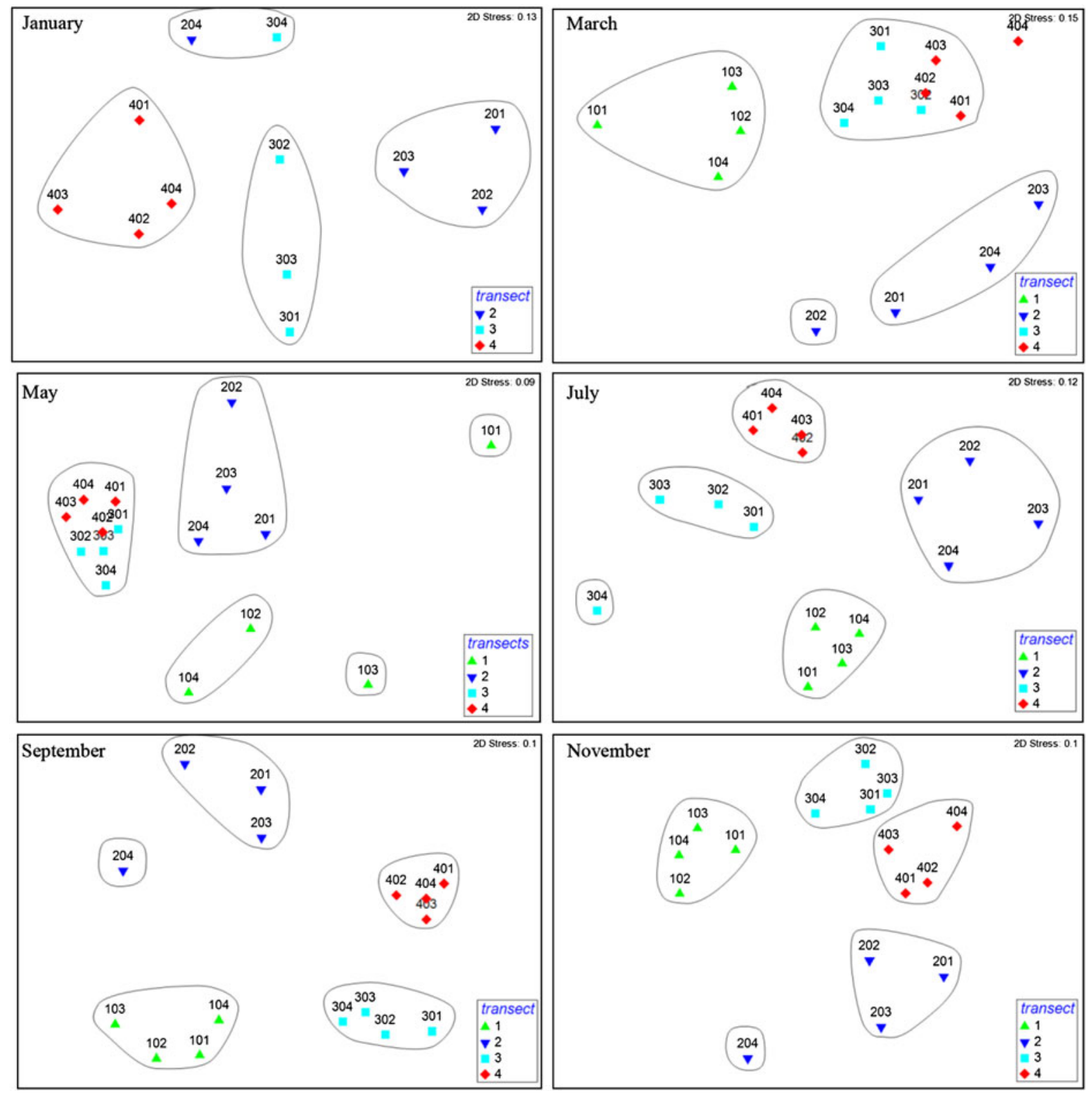

Fig. 5 Non-metric MDS plots in two dimensions for the macrobenthic data collected in each sampling month

\section{Discussion}

The macrobenthic communities studied contained a diverse range of invertebrate taxa dominated by polychaetes and crustaceans. The polychaete $L$. latreilli and the crustacean $P$. japonica were the most dominant species within the sediment at both the farm and reference sites, constituting 25.84 and $10.75 \%$ of the total abundance, respectively, across all sampling sites. The prevalent polychaete $L$. latreilli is distributed worldwide in temperate and warm waters and is very abundant in the northern Yellow Sea and the Bohai Sea. They construct semi-permanent burrows from which they selectively feed upon small particles of subsurface deposits (Watson et al., 1984; Petch, 1986; Renaud et al., 2007). The crustacean $P$. japonica plays an important role in the macrobenthic community here, the ecological traits of this animal are poorly 
Table 4 IMS along the four transects for all sampling months in 2011

\begin{tabular}{lcclr}
\hline & Transect 1 & Transect 2 & Transect 3 & Transect 4 \\
\hline January & - & $0.679(8.9 \%)$ & $0.463(26.3 \%)$ & $-0.123(66.5 \%)$ \\
March & $0.617(15.0 \%)$ & $0.031(58.5 \%)$ & $0.432(23.8 \%)$ & $0.679(9.4 \%)$ \\
May & $0.463(25.1 \%)$ & $-0.37(83.1 \%)$ & $0.833(7.6 \%)$ & $0.370(28.0 \%)$ \\
July & $0.216(43.1 \%)$ & $0.74(9.4 \%)$ & $0.216(41.0 \%)$ & $0.772(10.4 \%)$ \\
September & $-0.617(92.1 \%)$ & $0.123(49.8 \%)$ & $0.926(9.6 \%)$ & $0.278(43.2 \%)$ \\
November & $0.154(50.0 \%)$ & $0.617(15.7 \%)$ & $0.370(35.1 \%)$ & $0.463(21.8 \%)$ \\
\hline
\end{tabular}

Figures in parentheses are the $\%$ significance levels in a permutation test for the absence of seriation

known. According to the results of the Pearson correlation between the macrobenthic community structure and the environmental parameters, the presence of $P$. japonica showed strong correlations with TOC (Pearson correlation coefficient: -0.338 , $P<0.001$ ), whereas $L$. latreilli was unrelated to TOC. This result coincided with the assignations of the AMBI and m-AMBI analyses, in which $P$. japonica and $L$. latreilli were assigned into group 1 (very sensitive to organic enrichment) and group 2 (indifferent to enrichment), respectively. The abundance data of these two indicator species were applied to assess the potential effects of scallop mariculture by a generalized linear model, and there were no detectable trends along the distance from the aquaculture sites $(P>0.05)$. Owing to its sensitivity to organic accumulation, the widespread crustacean $P$. japonica can be potentially used in detection of organic pollution in the future.

In uniform habitats or homogenous regions, the structure of the macrobenthic communities are very similar ( $\mathrm{Li}$ et al., 2007, 2010). Due to the uniform habitat and the homogeneity of the region, the macrobenthic community around the Kongtong Islands in the present study had higher values of similarity (60-80\%) than in the adjacent areas of Rushan (40-60\%) (Li et al., 2009) and Ningjin (30\%) (Li et al., 2010). Changes in macrobenthic community structure along the distance gradient from the culture farm were evaluated using ANOSIM, MDS ordination, and SIMPER test. The macrobenthic community showed significant differences among sampling months and transect groups based on several statistical analyses. The influence imposed by season and transect was significant while scallop cultivation was not. The Seriation test coincided with the above conclusion and also indicated that the scallop farm was not the main factor to affect the composition of the macrobenthic community.

As the most commonly used biotic index in the European Water Framework Directive (WFD) (Borja et al., 2009), AMBI and m-AMBI have been proven to be efficient in detecting the degradation of habitat quality by different human pressures in different bodies of water along the European coast (Muxika et al., 2005; Pinto et al., 2009; Tomassetti et al., 2009), the Indian coast (Bigot et al., 2008), the USA (Borja et al., 2008), South America, and Hong Kong (Borja \& Muxika, 2005), especially in regard to mariculture (Borja et al., 2009). According to the guidelines for the use of AMBI (Borja \& Muxika, 2005), when the percentage of taxa that are not assigned is $>20 \%$, the result should be evaluated with care because there may be errors in the interpretation, and if it is $>50 \%$, the AMBI should not be used. Fortunately, our calculation fell below these standards. The calculated AMBI and $\mathrm{m}$-AMBI values indicated that there was no difference along the distance gradient, and the biological integrity of the research area remained good. The details of this type of analysis should be revised to adapt it to local water bodies and ecological systems (Pinto et al., 2009).

The Pearson \& Rosenberg (1978) paradigm predicts that benthic species richness and diversity should decrease with an increase in organic enrichment above a certain threshold level. Additional research has indicated that TOC appears to be toxic to benthic fauna at concentrations over $35 \mathrm{mg} \mathrm{g}^{-1}$ due to the deoxygenating effect of organic matter, whereas benthic assemblages do not show any evident alterations at TOC concentrations below $10 \mathrm{mg} \mathrm{g}^{-1}$ (Hyland et al., 2005). Most forms of bivalve shellfish culture contribute to 
enhanced sedimentation of organic material in the proximity of the mariculture units (Dahlbäck \& Gunnarsson, 1981; Hatcher et al., 1994; Grant et al., 1995), and in one study, suspended scallop culture increased the deposition of organic matter to approximately 2.46 times compared to the rate of a reference site without scallop culture (Zhou et al., 2006). However, in our study, the organic matter did not differ along the distance gradient, with an average of $17.27 \pm 6.05$ $\mathrm{mg} \mathrm{g}^{-1}$ (TOC percentage of weight) lower than the threshold of danger to benthic assemblages. The TOC concentration varied from 9 to $27 \mathrm{mg} \mathrm{g}^{-1}$, with the exceptions of 202-May (1.95 $\mathrm{mg} \mathrm{g}^{-1}$ ), 404-May $\left(1.53 \mathrm{mg} \mathrm{g}^{-1}\right)$ and $104-\mathrm{Nov}\left(1.55 \mathrm{mg} \mathrm{g}^{-1}\right)$, which fell below $9 \mathrm{mg} \mathrm{g}^{-1}$, and 303-Jan $\left(33.78 \mathrm{mg} \mathrm{g}^{-1}\right)$ and 304 -Sep (31.32 $\mathrm{mg} \mathrm{g}^{-1}$ ), which surpassed $30 \mathrm{mg} \mathrm{g}^{-1}$ but still remained lower than the threshold of $35 \mathrm{mg} \mathrm{g}^{-1}$.

In Sishili Bay, overcrowding in intensive scallop culture has led to negative effects including retarded growth and increased mortality of cultivated scallops, and has been commonly considered responsible for harmful algae blooms (Zhang \& Yang, 1999; Zhang et al., 2001; Zhou et al., 2006). The scallop farm near transects 2-4 had been in operation for over 20 years, whereas the farm near transect 1 had been installed for approximately 5 years. Minimal effects were observed in both areas, most likely because of the relatively low TOC concentration. In contrast to the study described by Crawford et al. (2003), this study area has suffered from high culture density and should be able to produce enough organic matter to negatively affect the macrobenthos; therefore, the strength of water flow is likely to be the key factor responsible for the negligible impact of scallop culture on this macrobenthic community and is inversely correlated with benthic impacts (Borja et al., 2009). The highest tidal flow was $28.5-30 \mathrm{~cm} \mathrm{~s}^{-1}$ during the ebb and flood tides, and water flow was typically $14.8 \mathrm{~cm} \mathrm{~s}^{-1}$ in the summer (Zhang \& Dong, 1990; Yanlin Cui, personal communication), disregarding the influence of the wind. The local current/tide appears to be strong enough to maintain the concentration of organic matter at a relatively low level. The magnitude and severity of the effects of shellfish culture vary from no or minimal negative effects to significantly positive and negative changes, depending on the outcome of a complex interplay between many operational and environmental factors, with the local hydrodynamic regime being a major factor (Cranford et al., 2009).
We conducted this study to verify if the macrobenthic assemblages will change along this distance gradient in the presence of scallop farm, and the reference sites were selected $500 \mathrm{~m}$ away from the farm sites in the light of the reference studies (da Costa \& Nalesso, 2006; Fabi et al., 2009). The mussel culture with similar or stronger current flow showed minimal or no negative effect on macrobenthic community with the reference sites varied from 500 to $600 \mathrm{~m}$. Five hundred meters may be not far enough to get beyond the influence of all effects from the scallop cultivation, the macrobenthic assemblages would still be expected to have changed along the distance gradient if the scallop farm really had affected the macrobenthic assemblages, even along a distance of $150 \mathrm{~m}$ (Tomassetti et al., 2009). Moreover, the particle size of sediment in Sishili bay showed over 70\% similarity (over $85 \%$ in the central part of the bay) (Liu et al., 2012a). In the light of the reference, sample of $0.1 \mathrm{~m}^{2}$ or smaller per station has been found sufficient to reliably distinguish different macrobenthic communities (Ferraro et al., 1994, 2006; Stenton-Dozey et al., 1999; Fabi et al., 2009; Tomassetti et al., 2009). Thus, three replicates and sample of $0.15 \mathrm{~m}^{2}$ per station should be sufficient to avoid Type II errors, which could result from a lack of sampling power and replication, for the highly homogenous nature of the sediment.

In the present study, all univariate and multivariate analyses indicated that the macrobenthic community significantly varied between different transect groups and sampling month groups, but not between different distance gradients. The results suggest that the effects of scallop cultivation on the macrobenthic community were negligible, and no major shifts were observed in the benthic infauna to species that are tolerant of high organic loading. This conclusion coincides with findings of previous studies focused on determining the effects of various types of shellfish mariculture (primarily mussel culture) on a macrobenthic community with a relatively high current velocity (mean speed of $10 \mathrm{~cm} \mathrm{~s}^{-1}$ and maximum speed over $30 \mathrm{~cm} \mathrm{~s}^{-1}$ ) (da Costa \& Nalesso, 2006; Cranford et al., 2009; Fabi et al., 2009). The shellfish farm apparently exerted negative effects on its macrobenthic community with a lower current velocity [mean current velocity from 3.16 to $10.21 \mathrm{~cm} \mathrm{~s}^{-1}$ (Hartstein \& Rowden, 2004); typical speed of $5 \mathrm{~cm} \mathrm{~s}^{-1}$ (Callier et al., 2008)]. Although our study could not define the exact threshold of current velocity and depth that are sufficient to disperse organic matter, the results of our 
study provided a baseline for future research. Quite different from the infauna in this research, large macroinvertebrate and benthic fishes, including top predators and ecologically and commercially important species, tend to respond positively to the presence of suspended shellfish culture (including mussel and scallop culture), and the abundance and productivity of these epifauna will increase with the protection of mariculture structure and with increasing habitat complexity (Inglis \& Gust, 2003; Clynick et al., 2008; D'Amours et al., 2008; Han et al., 2011). This research will be helpful for understanding the implications of situating scallop farms in coastal waters. As the high tidal flow is a key factor to affect the deposition of organic matter from the scallop cultivation activities, the scallop farms should be preferentially sited in areas of high tidal or current flow for minimal effects on the macrobenthic community.

Acknowledgments This work was financially supported by the National Scientific Foundation of China (No. 41006076), the Strategic Priority Research Program of Chinese Academy of Sciences (No. XDA05130703), and Key Laboratory for Ecological Environment in Coastal Areas, State Oceanic Administration (No. 201107). The authors would like to thank the anonymous reviewers for their valuable comments and suggestions to improve the quality of the paper.

\section{References}

Bigot, L., A. Gréare, J. M. Amouroux, P. Frouin, O. Maire \& J. C. Gaertner, 2008. Assessment of the ecological quality status of soft-bottoms in Reunion Island (tropical Southwest Indian Ocean) using AZTI marine biotic indices. Marine Pollution Bulletin 56(4): 704-722.

Borja, Á. \& I. Muxika, 2005. Guidelines for the use of AMBI (AZTI's marine biotic index) in the assessment of the benthic ecological quality. Marine Pollution Bulletin 50: 787-789.

Borja, Á. \& B. G. Tunberg, 2011. Assessing benthic health in stressed subtropical estuaries, eastern Florida, USA using AMBI and M-AMBI. Ecological Indicator 11: 295-303.

Borja, Á., D. M. Dauer, R. Díaz, R. J. Llansó, I. Muxika, J. G. Rodríguez \& L. Schaffner, 2008. Assessing estuarine benthic quality conditions in Chesapeake Bay: a comparison of three indices. Ecological Indicator 8: 395-403.

Borja, Á., J. G. Rodrígez, K. Black, A. Bodoy, C. Emblow, T. F. Fernandes, J. Forte, I. Karakassis, I. Muxika, T. D. Nickell, N. Papageorgiou, F. Pranovi, K. Sevastou, P. Tomassetti \& D. Angel, 2009. Assessing the suitability of a range of benthic indices in the evaluation of environmental impact of fin and shellfish aquaculture located in sites across Europe. Aquaculture 293(3-4): 231-240.
Callier, M. D., C. W. McKindsey \& G. Desrosiers, 2008. Evaluation of indicators used to detect mussel farm influence on the benthos: two case studies in the Magdalen Islands, Eastern Canada. Aquaculture 278: 77-88.

China Bureau of Fisheries, 2004-2011. China Fishery Statistical Yearbook. China Agriculture Press, Beijing (in Chinese).

Clarke, K. R. \& R. N. Gorley, 2001. PRIMER v5: User Manual/ Tutorial. PRIMER-E Ltd., Plymouth.

Clynick, B. G., C. W. McKindsey \& P. Archambault, 2008. Distribution and productivity of fish and macroinvertebrates in mussel aquaculture sites in the Magdalen islands (Québec, Canada). Aquaculture 283: 203-210.

Cranford, P. J., B. T. Hargrave \& L. I. Doucette, 2009. Benthic organic enrichment from suspended mussel (Mytilus edulis) culture in Prince Edward Island, Canada. Aquaculture 292(3-4): 189-196.

Crawford, C. M., C. K. A. Macleod \& I. M. Mitchell, 2003. Effects of shellfish farming on the benthic environment. Aquaculture 224: 117-140.

D'Amours, O., P. Archambault, C. W. McKindsey \& L. E. Johnson, 2008. Local enhancement of epibenthic macrofauna by aquaculture activities. Marine Ecology Progress Series 371: 73-84.

da Costa, K. G. \& R. C. Nalesso, 2006. Effects of mussel farming on macrobenthic community structure in Southeastern Brazil. Aquaculture 258: 655-663.

Dahlbäck, B. \& L. A. H. Gunnarsson, 1981. Sedimentation and sulfate reduction under a mussel culture. Marine Biology 63: 269-275.

Dubois, S., J. C. Marin-Léal, M. Ropert \& S. Lefebvre, 2007. Effects of oyster farming on macrofaunal assemblages associated with Lanice conchilega tubeworm populations: a trophic analysis using natural stable isotopes. Aquaculture 271: 336-349.

FAO, 2010. The State of World Fisheries and Aquaculture. FAO, Rome.

Fabi, G., S. Manoukian \& A. Spagnolo, 2009. Impact of an open-sea suspended mussel culture on macrobenthic community (Western Adriatic Sea). Aquaculture 289(1-2): 54-63.

Ferraro, S. P., R. C. Swartz, F. A. Cole \& W. A. Deben, 1994. Optimum macrobenthic sampling protocol for detecting pollution impacts in the southern California Bight. Environmental Monitoring and Assessment 29: 127-153.

Ferraro, S. P., F. A. Cole \& A. R. Olsen, 2006. A more costeffective emap benthic macrofaunal sampling protocol. Environmental Monitoring and Assessment 116: 275-290.

Gaudêncio, M. J. \& H. N. Cabral, 2007. Trophic structure of macrobenthos in the Tagus estuary and adjacent coastal shelf. Hydrobiologia 587: 241-251.

Gibbs, T. M., 2007. Sustainability performance indicators for suspended bivalve aquaculture activities. Ecological Indicators 7: 94-107.

Gilbert, F., P. Souchu, M. Bianchi \& P. Bonin, 1997. Influence of shellfish farming activities on nitrification, nitrate reduction to ammonium and denitrification at the water sediment interface of the Thau lagoon, France. Marine Ecology Progress Series 151: 143-153.

Grall, J. \& M. Glémarec, 1997. Using biotic indices to estimate macrobenthic community perturbations in the Bay of Brest. 
Estuarine, Coastal and Shelf Science 44(Supplement 1): 43-53.

Grant, J., A. Hatcher, D. B. Scott, P. Pocklington, C. T. Schafer \& G. V. Winters, 1995. A multidisciplinary approach to evaluating impacts of shellfish aquaculture on benthic communities. Estuaries 18: 124-144.

Grant, C., P. Archambault, F. Olivier \& C. McKindsey, 2012. Influence of 'bouchot' mussel culture on the benthic environment in a dynamic intertidal system. Aquaculture Environment Interactions 2: 117-131.

Han, Q. X., B. Q. Li, Q. Y. Han, Y. Zhang, Y. Q. Wang, Q. C. Wang \& D. Y. Liu, 2011. Preliminary study of the impact of fishery trawling on epifauna community in the coastal water of Weihai Port. Marine Science Bulletin 30(2): 121-126. in Chinese with English abstract.

Hartstein, N. D. \& A. A. Rowden, 2004. Effect of biodeposits from mussel culture on macroinvertebrate assemblages at site of different hydrodynamic regime. Marine Environmental Research 57: 339-357.

Hatcher, A., J. Grant \& B. Schofield, 1994. Effects of suspended mussel culture (Mytilus spp.) on sedimentation, benthic respiration and sediment nutrient dynamics in a coastal bay. Marine Ecology Progress Series 115: 219-235.

Hyland, J., L. Balthis, I. Karakassis, P. Magni, A. Petrov, J. Shine, O. Vestergaard \& R. Warwick, 2005. Organic carbon contents of sediments as an indicator of stress in the marine benthos. Marine Ecology Progress Series 295: 91-103.

Inglis, G. J. \& N. Gust, 2003. Potential indirect effects of shellfish culture on the reproductive success of the benthic predators. Journal of Applied Ecology 40: 1077-1089.

Jia, Y. R., X. J. Liu, Y. L. Sun \& C. Q. Sun, 2007. Argumentation of sewage discharge mixing zone's area of Xin'an River sewage plant of Yantai. Marine Science Bulletin 26(2): 33-37. in Chinese with English abstract.

Kaiser, M. J., 2000. Ecological effects of shellfish cultivation. In Black, K. D. (ed.), Environmental Impacts of Aquaculture. Sheffield Academic Press, Sheffield, UK: 51-75.

Li, X. Z., B. Q. Li, H. F. Wang, S. Q. Wang, J. B. Wang \& B. L. Zhang, 2007. Macrobenthic community characters of Zhubi Reef, Nansha Islands, South China Sea. Acta Zoologica Sinica 53(1): 83-94. in Chinese with English abstract.

Li, X. Z., B. Q. Li, H. F. Wang, J. B. Wang, X. C. Wang, J. Zhou, Q. X. Han, L. Ma, C. Dong \& B. L. Zhang, 2009. Community structure of macrobenthos in coastal water off Rushan, Southern Shandong Peninsula, and the relationships with environmental factors. Acta Oceanologica Sinica 28(5): 81-93. in Chinese with English abstract.

Li, B. Q., X. Z. Li, H. F. Wang, J. B. Wang, Q. X. Han, C. Dong, L. Ma \& B. L. Zhang, 2010. The relationship between softbottom macrobenthic communities and environmental variables off Ningjin, eastern Shandong Peninsula. Acta Oceanologica Sinica 29(6): 1-11.

Liu, B. Z., 2003. Study on the Population genetics of Bay Scallop Argopecten irradians and the Molecular Phylogeny of Pectinidae. Graduate School of the Chinese Academy of Sciences, Qingdao: 1-105 (in Chinese with English abstract).

Liu, D. Y., X. H. Shen, Y. J. Wang, Y. J. Chen \& L. Li, 2012a. Tracking the sources of organic matter in the surface sediments of Sishili Bay, northern Yellow Sea and the environmental implication. Acta Oceanologica Sinaca 34(5): 205-212. in Chinese with English abstract.

Liu, D. Y., Y. J. Shi, B. P. Di, Q. L. Sun, Y. Q. Wang, Z. J. Dong \& H. B. Shao, 2012b. The impact of different pollution sources on modern dinoflagellate cysts in Sishili Bay, Yellow Sea, China. Marine Micropaleontology 84-85: $1-13$.

Mirto, S., T. La Rosa, R. Danovaro \& A. Mazzola, 2000. Microbial and meiofaunal response to intensive mussel farm biodeposition in coastal sediments of the Western Mediterranean. Marine Pollution Bulletin 40: 244-252.

Muxika, I., Á. Borja \& W. Bonne, 2005. The suitability of the marine biotic index (AMBI) to new impact sources along European coasts. Ecological Indicators 5(1): 19-31.

Pearson, T. H. \& R. Rosenberg, 1978. Macrobenthic succession in relation to organic enrichment and pollution of the marine environment. Oceanographic Marine Biology Annual Review 16: 229-311.

Petch, D. A., 1986. Selective deposit-feeding by Lumbrineris cf. latreilli (Polychaeta: Lumbrineridae), with a new method for assessing selectivity by deposit-feeding organisms. Marine Biology 93: 443-448.

Pinto, R., J. Patrício, A. Baeta, B. D. Fath, J. M. Neto \& J. C. Marques, 2009. Review and evaluation of estuarine biotic indices to assess benthic condition. Ecological Indicators 9(1): 1-25.

Renaud, P. E., M. Wlodarska-Kowalczuk, H. Trannum, B. Holte, J. M. Weslawsk, S. Cochrane, S. Dahle \& B. Gulliksen, 2007. Multidecadal stability of benthic community structure in a high-Arctic glacial fjord (van Mijenfjord, Spitsbergen). Polar Biology 30: 295-305.

Shin, P. K. S., Z. G. Huang \& R. S. S. Wu, 2004. An updated baseline of subtropical macrobenthic communities in Hong Kong. Marine Pollution Bulletin 49: 128-135.

Smaal, A. C., 1991. The ecology and cultivation of mussels: new advances. Aquaculture 94: 245-261.

Smith, J. \& S. E. Shackley, 2004. Effects of a commercial mussel Mytilus edulis lay on a sublittoral, soft sediment benthic community. Marine Ecology Progress Series 282: 185-191.

Stenton-Dozey, J. M. E., L. F. Jackson \& A. J. Busby, 1999. Impact of mussel culture on macrobenthic community structure in Saldanha Bay, South Africa. Marine Pollution Bulletin 39: 357-366.

Tomassetti, P., E. Persia, I. Mercatali, D. Vani, V. Marussso \& S. Porrello, 2009. Effects of mariculture on macrobenthic assemblages in a western Mediterranean site. Marine Pollution Bulletin 58: 533-541.

Watson, G. F., A. I. Robertson \& M. J. Littlejohn, 1984. Invertebrate macrobenthos of the seagrass communities in Western Port, Victoria. Aquatic Botany 18: 175-197.

Yang, H. S. \& Y. Zhou, 1998. Progress in studies on effect of filter-feeding bivalve on environment of mariculture area. Marine Science 22(2): 42-44. in Chinese with English abstract.

Zhang, R. A. \& Y. Z. Dong, 1990. Analysis of conditions of natural environment in sea areas for pollutant discharge and the study on pathways of pollutant transport in Yantai. Coastal Engineering 9(2): 35-44. in Chinese with English abstract. 
Zhang, F. S. \& H. S. Yang, 1999. Analysis of the causes of mass mortality of farming Chlamys farreri in summer in coastal areas of Shandong, China. Marine Sciences 23(1): 44-47. in Chinese with English abstract.

Zhang, F. S., Y. Z. He, L. X. Qi \& L. N. Sun, 1997. Studies on the restoration of cultured bay scallop Argopecten irradians through reintroduction of broodstock. Oceanologia et Limnologia Sinica 28(2): 146-152. in Chinese with English abstract.

Zhang, T., H. S. Yang, P. Wang, Y. C. He \& F. S. Zhang, 2001. The factors affecting meat condition and growth rate of
Farreri's scallop Chlamys (Azumapecten) farreri in Sishiliwan Bay, Yantai. Marine Fisheries Research 22(1): 25-31. in Chinese with English abstract.

Zhou, Y., H. S. Yang, T. Zhang, S. L. Liu, S. M. Zhang, Q. Liu, J. H. Xiang \& F. S. Zhang, 2006. Influence of filtering and biodeposition by the cultured scallop Chlamys farreri on benthic-pelagic coupling in a eutrophic bay in China. Marine Ecology Progress Series 317: 127-141. 